\title{
Glycogen synthase kinase-3 $\beta$ inhibition depletes the population of prostate cancer stem/progenitor-like cells and attenuates metastatic growth
}

\author{
Jan Kroon ${ }^{1}$, Lars S. in 't Veld ${ }^{1}$, Jeroen T. Buijs ${ }^{1}$, Henry Cheung ${ }^{1}$, Geertje van der \\ Horst $^{1}$, Gabri van der Pluijm ${ }^{1}$ \\ ${ }^{1}$ Department of Urology, Leiden University Medical Center, Leiden, the Netherlands \\ Correspondence to: Gabri van der Pluijm, email: G.van_der_Pluijm@lumc.nl \\ Keywords: Cancer Stem Cells, GSK-3ß, Metastasis, Prostate Cancer, Wnt signaling \\ Received: October 16, $2013 \quad$ Accepted: December 3, $2013 \quad$ Published: December 5, 2013
}

This is an open-access article distributed under the terms of the Creative Commons Attribution License, which permits unrestricted use, distribution, and reproduction in any medium, provided the original author and source are credited.

\section{ABSTRACT:}

Cancer cells with stem or progenitor properties play a pivotal role in the initiation, recurrence and metastatic potential of solid tumors, including those of the human prostate. Cancer stem cells are generally more resistant to conventional therapies thus requiring the characterization of key pathways involved in the formation and/ or maintenance of this malignant cellular subpopulation.

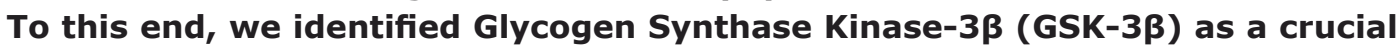
kinase for the maintenance of prostate cancer stem/progenitor-like cells and pharmacologic inhibition of GSK-3 $\beta$ dramatically decreased the size of this cellular subpopulation. This was paralleled by impaired clonogenicity, decreased migratory potential and dramatic morphological changes. In line with our in vitro observations, treatment with a GSK-3 $\beta$ inhibitor leads to a complete loss of tumorigenicity and a decrease in metastatic potential in preclinical in vivo models. These observed antitumor effects appear to be largely Wnt-independent as simultaneous Wnt inhibition does not reverse the observed antitumor effects of GSK-3 $\beta$ blockage. We found that GSK-3 $\beta$ activity is linked to cytoskeletal protein F-actin and inhibition of GSK-3 $\beta$ leads to disturbance of F-actin polymerization. This may underlie the dramatic effects of GSK-3 $\beta$ inhibition on prostate cancer migration. Furthermore, GSK-3 $\beta$ inhibition led to strongly decreased expression of several integrin types including the cancer stem cell-associated a2 $\beta 1$ integrin. Taken together, our mechanistic observations highlight the importance of GSK-3 $\beta$ activity in prostate cancer stemness and may facilitate the development of novel therapy for advanced prostate cancer

\section{INTRODUCTION}

Prostate cancer is the most common diagnosed male malignancy with over 900000 new cases and over 250 000 deaths worldwide in 2008 [1]. At early stage, when the disease is still organ-confined, treatment options include prostatectomy or radiation. Unfortunately, 20$25 \%$ of patients will experience relapse within 5 years of treatment [2]. Once prostate cancer has spread beyond the prostate it is incurable and, at this stage, androgen deprivation therapy is the standard treatment. However, virtually all patients relapse with castration-resistant prostate cancer (CRPC) within 1-3 years [3-5]. Despite the introduction of new agents to treat metastatic CRPC, a major challenge remains to improve survival of these patients. A principal limitation of docetaxel, the current first-line therapy for metastatic CRPC, is initial or acquired resistance which largely reduces its anti-tumor efficacy. Hence, the identification of specific pathways involved in therapy resistance is pivotal for the development of novel treatment options for advanced prostate cancer.

An increasing number of studies demonstrate that a small subpopulation of transformed cells with stemand progenitor properties, also referred to as cancer stem cells (CSCs), is involved in prostate cancer initiation, metastasis and the resistance to current therapies [6]. While $\mathrm{ALDH}^{\mathrm{HIGH}}, \mathrm{CD} 44+$ and $\alpha 2$-integrin ${ }^{\mathrm{HIGH}} \mathrm{CSCs}$ in primary prostate cancer predominantly display a basal 
cell phenotype, the stem/progenitor cells that survive androgen-deprivation therapy and re-initiate tumor growth exhibit a luminal progenitor phenotype [7-10]. The notion that CSCs play an essential role in resistance to conventional therapies warrants the characterization of key pathways and proteins for the formation and maintenance of tumor- and metastasis-initiating cells. Selective targeting of such pathways is, therefore, urgently required.

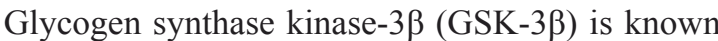
to play a role in several cellular processes such as cell cycle control, proliferation, differentiation and apoptosis [11]. GSK-3 $\beta$ can phosphorylate a range of substrates including glycogen synthase, cyclin D1/E and c-MYC but is typically known for its role in the Wnt signaling pathway in which it acts as a negative regulator of Wnt effector molecule $\beta$-catenin [12]. Here, GSK-3 $\beta$-mediated phosphorylation of $\beta$-catenin leads to ubiquitination and subsequent proteasomal degradation of the latter. In several cancer types, uncontrolled Wnt signaling was shown to be involved in the development of several solid tumors $[13,14]$.

In this study, the importance of GSK-3 $\beta$ activity for the maintenance of prostate cancer stem/progenitorlike subpopulation and its involvement in metastasis was evaluated. We show that GSK-3 $\beta$ provides a potential therapeutic target that is functionally involved in prostate cancer stem cell maintenance, tumorigenicity and metastasis in vivo.

\section{RESULTS}

\section{GSK-3 $\beta$ Inhibition Affects Cellular Morphology}

The cellular morphology upon treatment with selective GSK-3 $\beta$ inhibitor GIN $[17,18]$ revealed a change from a stellate mesenchyme-like shape to a more round shaped morphology in PC-3M-Pro4 cells (Suppl. Fig. 1a, Day $1 \& 3$ ). This morphological effect was completely reversible, as removal of GIN resulted in restored cell growth and normalized cellular morphology (Suppl. Fig. 1a, Day 6 \& 8, lower row). Continued GSK-3 $\beta$ inhibition led to a long-lasting effect on cellular morphology (Suppl. Fig 1a, Day 6 \& 8, center row).

\section{GSK-3 $\beta$ Inhibition Leads to an Induction of Wnt Signaling}

GSK-3 $\beta$ is mostly known for its inhibitory role in the Wnt signaling pathway, in which it phosphorylates $\beta$-catenin which targets the latter for proteasomal degradation and thereby prevents Wnt signaling [14]. To confirm this in our cells, PC-3 cells were transiently transfected with a bioluminescent canonical Wnt- reporter construct, BAT-Firefly luciferase [19, 20], and CAGGSpromotor-Renilla luciferase as a control for transfection efficiency. As expected, GSK-3 $\beta$ inhibition led to a strong, 5-fold, induction of Firefly luciferase/ Renilla luciferase ratio, indicating enhanced Wnt signaling (Fig. 1, left). This dose-dependent induction of Wnt signaling upon GSK-3 $\beta$ inhibition was reversed by simultaneous incubation with the downstream inhibitor of Wnt signaling, PNU-74654, in which the $100 \mu \mathrm{M}$ dose led to a near complete reversal of the induced Wnt signaling in PC-3 cells (-72\%, Fig. 1, left). In PC-3M-Pro4 cells, a 400-fold induction of Wnt signaling was observed upon GSK-3 $\beta$ inhibition which was partially reversed by addition of $30 \mu \mathrm{M}$ PNU-74654 (-52\%, Fig. 1, right).

\section{GSK-3ß Inhibition and Stem/Progenitor-like Cells}

Based on these initial experiments, the dosage of $100 \mathrm{nM}$ GIN was selected for the following functional experiments. We evaluated the effect of GSK-3 $\beta$ inhibition on the prostate cancer stem/progenitor-like subpopulation, and subsequently on functional cellular characteristics such as the clonogenic and migratory capacity. GSK-3 $\beta$ inhibition almost completely eradicated the subpopulation of ALDEFLUOR+ or ALDH ${ }^{\mathrm{HIGH}}$ stem/progenitor-like cells in PC-3 and PC-3M-Pro4 cells [10], while C4-2B4 and DU-145 cells were not significantly affected (Fig. 2a). In line with this, the mRNA expression of 5 out of 7 tested ALDH isoforms was significantly downregulated in PC3M-Pro4 cells upon GSK-3 $\beta$ inhibition (Suppl. Fig. 2a). In addition, expression of genes known to be critically

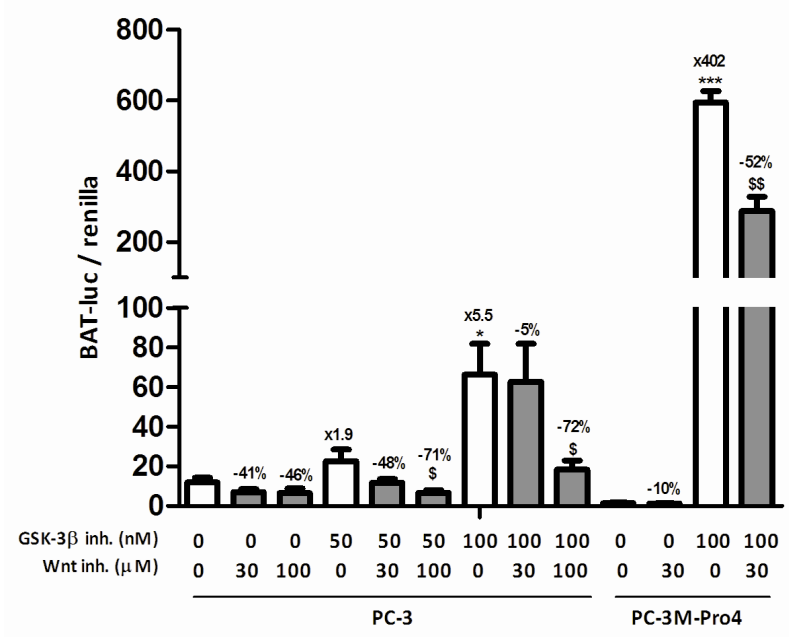

Figure 1: The effect of GSK-3 $\beta$ inhibition on Wnt signaling in prostate cancer cell lines. Wnt reporter activity in transiently transfected PC-3 and PC-3M-Pro4 cells after pretreatment with 30-100 $\mu \mathrm{M}$ PNU-74654 and/or 50-100 $\mathrm{nM}$ GIN for 24 hours. The figure comprises two independent experiments. $* \mathrm{p}<0.05$ versus control; $* * * \mathrm{p}<0.001$ versus control; $\$ p<0.05$ versus GIN-treated. 
involved in self-renewal $[8,10,21]$ and bone metastasis [22] were investigated which revealed a significant reduction of NANOG, Oct-4 and $\alpha 2$-integrin, and showed similar trends for Bmi-1 and CD44 (Suppl. Fig. 2b).

Next, GSK-3 $\beta$ inhibition strongly attenuated the
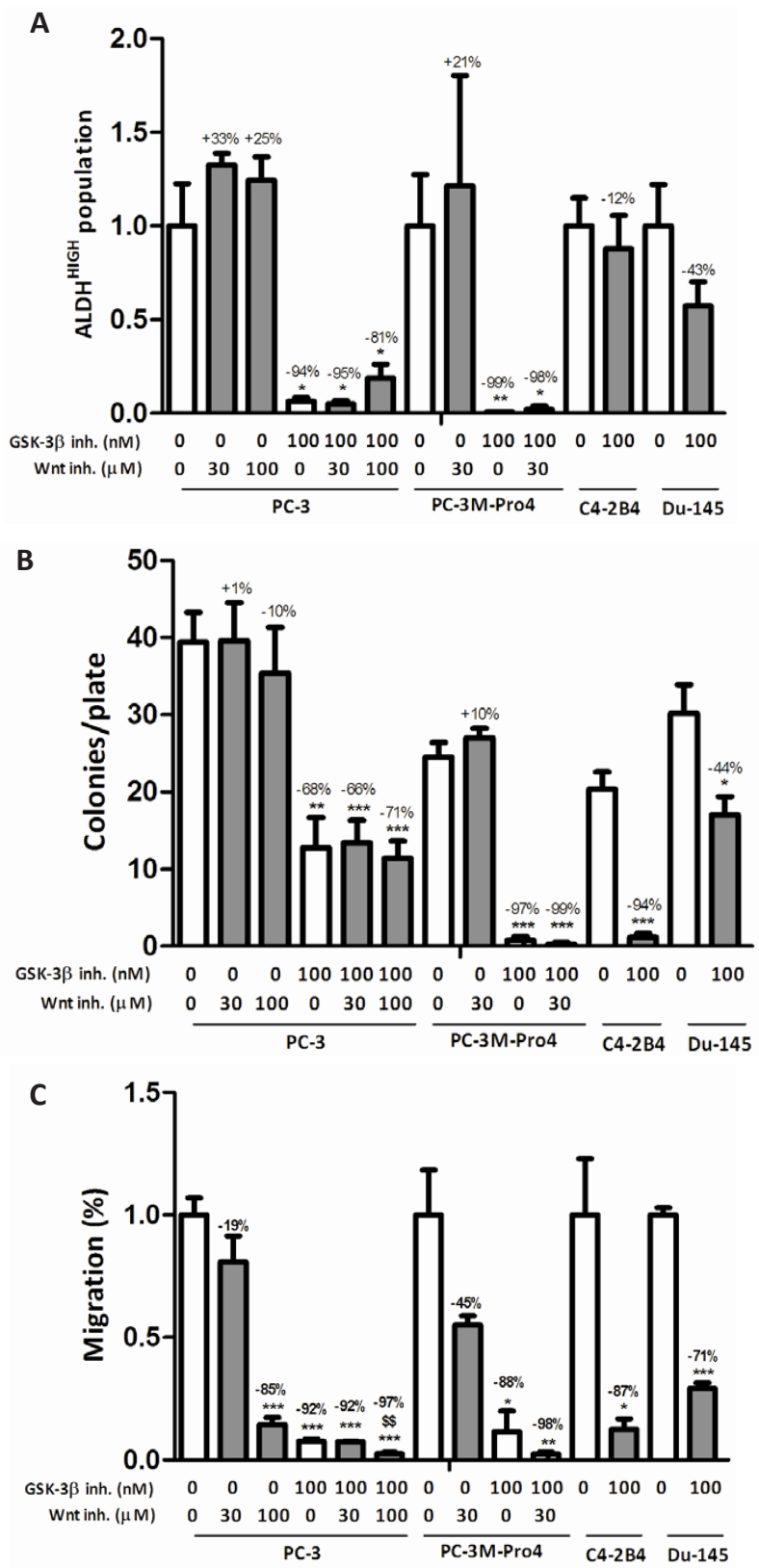

Figure 2: The effect of GSK-3 $\beta$ inhibition on the stem/ progenitor subpopulation, clonogenic and migratory potential. (a) The effect of treatment with 30-100 $\mu \mathrm{M}$ PNU74654 and/or 50-100 nM GIN on (a) ALDH ${ }^{\mathrm{HIGH}}$ subpopulation after 48 hours (\% $\mathrm{ALDH}^{\mathrm{HIGH}}$ subpopulation of untreated: $\mathrm{PC}-3$, $4.5 \pm 1.0 \%$; PC-3M-Pro4, 25.8 $\pm 7.1 \%$; C4-2B4, 19.6 $\pm 2.9 \%$; DU$145,2.3 \pm 0.5 \%$ ), (b) clonogenic potential after 7 days and (c) migratory capacity after 16 hours. All figures comprise two or three independent experiments. ${ }^{*} \mathrm{p}<0.05$ versus control; $* * \mathrm{p}$ $<0.01$ versus control; $* * * \mathrm{p}<0.001$ versus control; $\$ \mathrm{~S} \mathrm{p}<0.01$ versus GIN-treated. clonogenic capacity of tested prostate cancer cell lines PC-3 (68\% inhibition), PC-3M-Pro4 (-97\%), C4-2B4 $(-94 \%)$ and DU-145 (-44\%) (Fig. 2b). In addition to a decrease in colony number, the colonies that were observed upon GSK-3 $\beta$ inhibition were much smaller then under vehicle-treated conditions (not shown). The strong effects observed in multiple prostate cancer cell lines

A

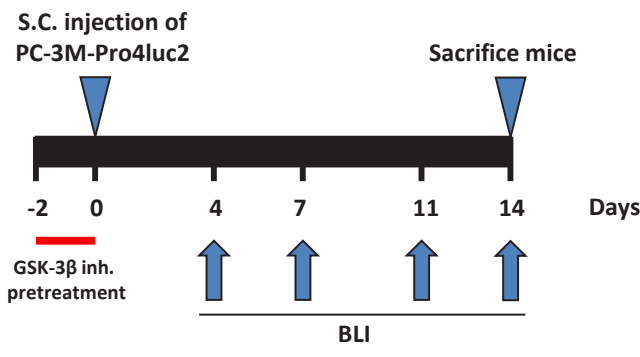

B

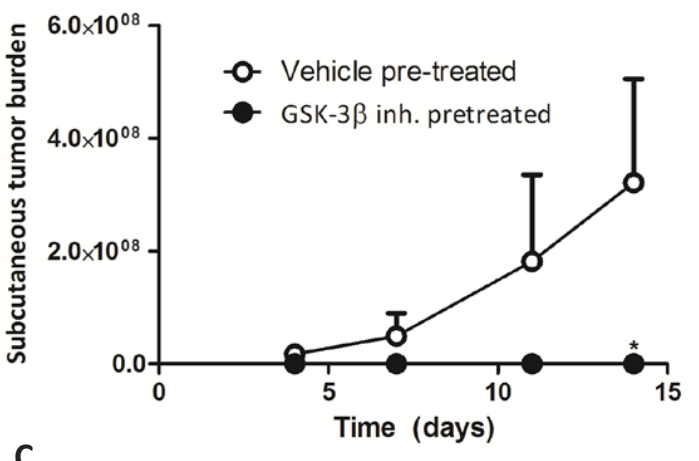

C

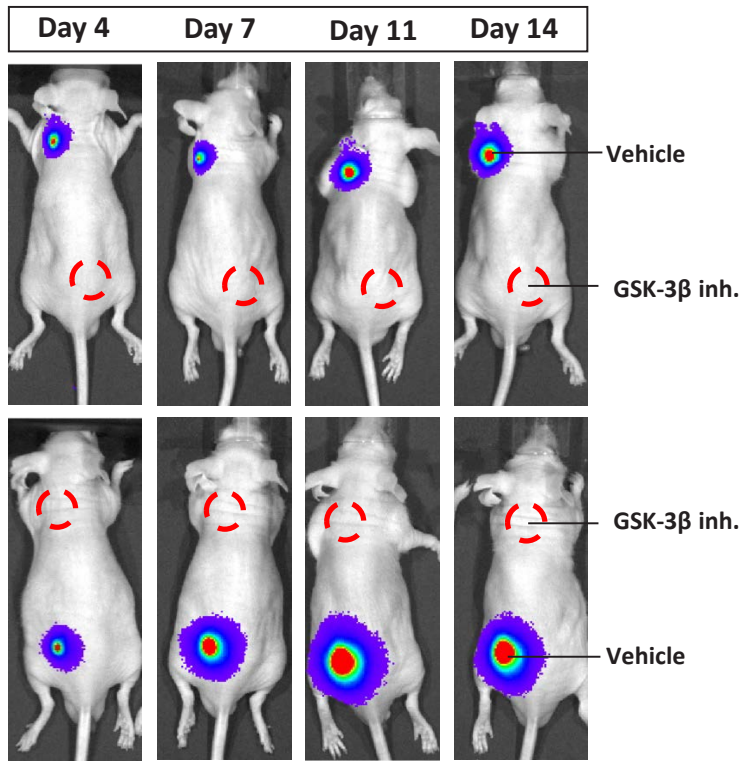

Figure 3: The effect of GIN pretreatment in vitro on tumorigenic potential in vivo. $\mathrm{PC}-3 \mathrm{M}$-Pro4luc2 cells were pretreated with vehicle or $100 \mathrm{nM}$ GIN for 48 hours prior to subcutaneous inoculation in nude mice ( $\mathrm{n}=10$ per group). (a) Experimental schedule. (b) Subcutaneous tumor burden. (c) Representative examples of bioluminescent images. $* \mathrm{p}<0.05$ versus control. 
suggest cell-type independency of GSK-3 $\beta$ inhibition. Also, inhibition of GSK-3 $\beta$ activity resulted in a strong decrease in cellular migration of all tested prostate cancer cell lines; PC-3 (92\% inhibition), PC-3M-Pro4luc2 (-88\%), C4-2B4 (-87\%) and DU-145 (-71\%) (Fig. 2c). Interestingly, while $\mathrm{C} 4-2 \mathrm{~B} 4$ cells lost their clonogenic and migratory potential upon GSK-3 $\beta$ inhibition, the $\mathrm{ALDH}^{\mathrm{HIGH}}$ population remained unaffected. This shows that the functional effects of GSK-3 $\beta$ inhibition are not necessarily accompanied by a change in the activity of ALDH enzymes. To exclude that any of the effects described above could be attributed to increased cell death upon GSK-3 $\beta$ inhibition, the percentage of trypan blue-positive cells were counted (Suppl. Fig. 1b) which revealed no significant increase in cell death.

To evaluate if the stimulation of Wnt signaling was causally involved in the observed effects, canonical Wnt signaling was blocked using PNU-74654. This did not reverse the diminishing effects on the stem/progenitorlike population, the anti-clonogenic and the anti-migratory

A

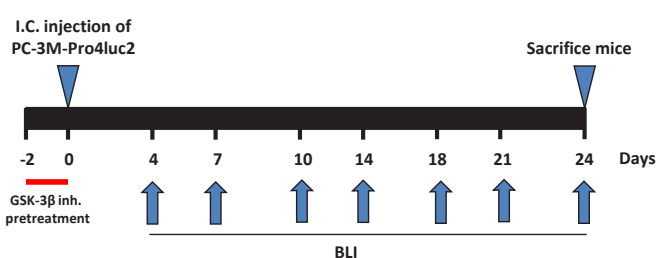

B

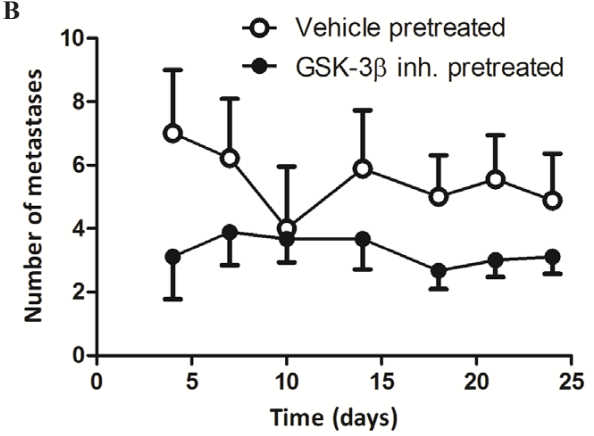

C

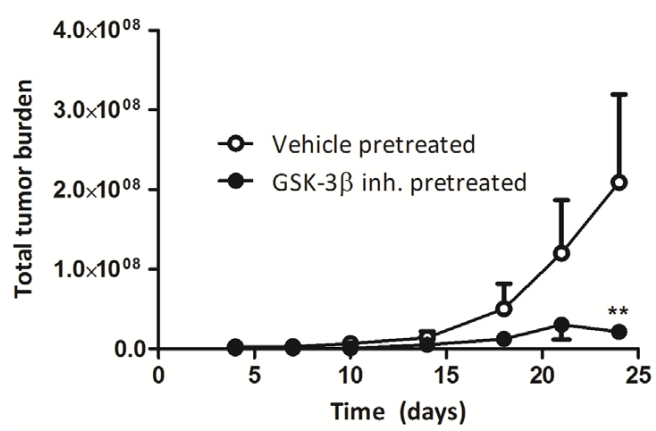

Figure 4: The effect of GIN pretreatment in vitro on metastatic potential in vivo. $\mathrm{PC}-3 \mathrm{M}$-Pro4luc2 cells were pretreated with vehicle or $100 \mathrm{nM}$ Gin for 48 hours prior to inoculation in the left cardiac ventricle of nude mice $(n=9$ per group). (a) Experimental schedule. (b) Quantification of the total number of metastases and (c) total tumor burden. $* * p<0.01$ versus control. effects of GSK-3 $\beta$ inhibition, suggesting that GIN exerts its effects independent of Wnt signaling. Notably, 100 $\mu \mathrm{M}$ PNU-74654 significantly reduced migratory potential under basal and GSK-3 $\beta$ inhibitory conditions, suggesting that active Wnt signaling may, in fact, be positively correlated with migration of prostate cancer cells.

\section{GSK-3 $\beta$ Inhibition, Tumorigenicity and Metastasis in vivo}

Based on the strong effects of GSK-3 $\beta$ inhibition on the stem/progenitor cell subpopulation in vitro, we evaluated the effects of GIN pretreatment on prostate cancer tumorigenicity and metastatic potential in vivo. To this end, PC-3M-Pro4luc2 cells were pretreated with vehicle or GIN in vitro for 48 hours prior to subcutaneously inoculation in Balb-c nu/nu mice (Fig. 3a). GIN pretreatment resulted in a complete loss of tumorigenic potential, resulting in a significant decrease of subcutaneous tumor burden as soon as 14 days after tumor inoculation (Fig. 3b, 3c).

Next, we assessed the potential anti-metastatic effects of GSK-3 $\beta$ inhibition in a xenograft model of experimentally-induced bone metastasis. PC-3M-Pro4luc2 cells were, again, pretreated with vehicle or GIN for 48 hours and inoculated into the left cardiac ventricle of Balb-c nu/nu mice (Fig. 4a). As expected, vehiclepretreated prostate cancer cells readily formed bone metastases at multiple sites throughout the body (Fig. 4b, 4c) [10]. Strikingly, pretreatment with GIN led to a nearcomplete loss of metastatic tumor burden in this model (Fig. 4c).

\section{GSK-3及 Inhibition Disturbs F-actin Polymerization and Reduces Integrin Expression}

The results described above highlight a strong attenuating effect of GSK-3 $\beta$ inhibition on cancer stemness and migration in vitro and tumorigenic and metastatic potential in vivo. Based on our observation that the cellular morphology of prostate cancer cells was disturbed following GSK-3 $\beta$ inhibition and a previous study pointing out a link between GSK-3 $\beta$ and F-actin [23], we performed a DAPI/Phalloidin double staining to monitor F-actin polymerization. This clearly revealed a strong reduction of $\mathrm{F}$-actin polymerization upon GSK-3 $\beta$ inhibition (Fig. 5a). In accordance with our data on the stem/progenitor subpopulation, clonogenic ability and migration, co-incubation with Wnt inhibitor PNU-74654 did not restore F-actin polymerization in PC-3 or PC-3MPro4 prostate cancer cells (Fig. 5a). Previously, a causal link between $\mathrm{F}$-actin and several integrin isoforms has been described $[21,24,25]$. Based on this, we examined the expression of $\alpha v$ - (ITGAV), $\alpha 2$ - (ITGA2) and $\alpha 6$ integrin (ITGA6) in GIN-treated PC-3M-Pro4 cells and 
this revealed a significant reduction in the expression of $\alpha 2$ (-57\%), $\alpha 6$-integrin (-74\%) and $\alpha$ v-integrin (-26\%) (Figure $5 b)$.

\section{DISCUSSION}

The importance of stem/progenitor cells in prostate carcinogenesis, cancer repopulation, therapy response and metastatic potential is increasingly being recognized [7-10]. Accumulating evidence suggests that CSCs are highly resistant to conventional therapies for the treatment of (advanced) prostate cancer, which warrants further characterization of pathways and target genes essential for these tumorigenic and metastasis-initiating cells. Identification and selective targeting of such key pathways or proteins may provide a highly promising approach to deplete this highly malignant subpopulation of cells in prostate carcinoma. In this study, we established the role of GSK- $3 \beta$ in the acquisition and maintenance of an invasive, tumorigenic and metastatic phenotype in human prostate cancer cells using a selective, small molecule inhibitor of GSK-3 $\beta$.

Previously, we showed that ALDH ${ }^{\mathrm{HIGH}}$ stem/ progenitor subpopulation of human prostate cancer display increased clonogenic and migratory potential in vitro and
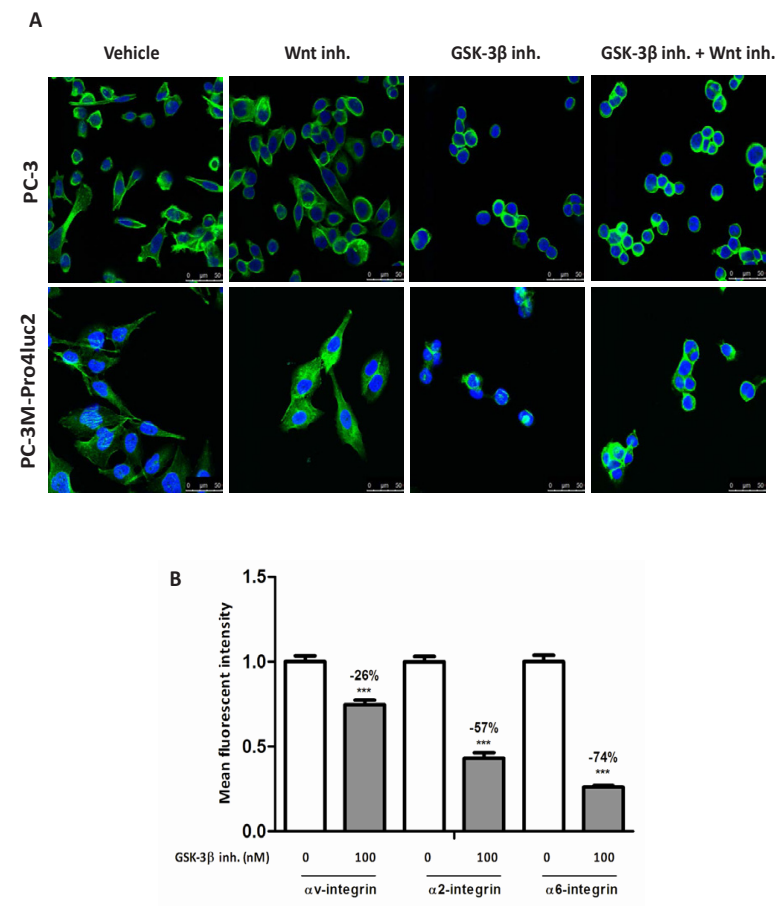

Figure 5: The effect of GSK-3 $\beta$ inhibition on F-actin polymerization and integrin expression. (a) $\mathrm{PC}-3$ or $\mathrm{PC}$ 3M-Pro4 cells were treated with $100 \mu \mathrm{M}$ PNU-74654 and/or 100 nM GIN for 48 hours. F-actin polymerization was visualized using Phalloidin (green) and the nucleus was visualized using DAPI (blue). (b) PC-3M-Pro4 cells were treated with $100 \mathrm{nM}$ GIN for 48 hours and integrin expression was monitored using flow cytometry. $* * * \mathrm{p}<0.01$ versus control. enhanced orthotopic and metastatic growth in vivo [10]. We now show that blockage of GSK-3 $\beta$ activity leads to a massive reduction in the size of this highly tumorigenic cellular subpopulation of $\mathrm{ALDH}^{\mathrm{HIGH}}$ prostate cancer cells with a concomitant reduction in clonogenic and migratory potential of human prostate cancer cell lines. Similar findings of GSK-3 $\beta$ inhibition were described for glioblastoma, in which a reduction of stem cell markers was described upon GSK-3 $\beta$ inhibition subsequently leading to impaired neurosphere formation and lessened clonogenicity [26, 27].

The striking anti-tumor effects of GSK-3 $\beta$ inhibition in vitro were paralleled by a significant decrease in subcutaneous growth and bone metastasis in vivo of the osteotropic prostate cancer cell line PC-3M-Pro4. Previous findings with other GSK-3 $\beta$ inhibitors (e.g. $\mathrm{LiCl}, \mathrm{TDZD} 8)$ in subcutaneously xenografted cancer cells further support this notion $[28,29]$. In addition, other studies show anti-tumor effects of GSK-3 $\beta$ inhibition on prostate cancer cells in vitro, but these effects were predominantly attributed to modulating effects on the androgen-receptor axis [30,31], or changes in cell cycle proteins [23]. Although the androgen receptor may be partially responsible for decreased growth upon the suppression of GSK-3 $\beta$ activity in the tested androgenreceptor positive cell lines, it cannot explain the robust effects in the androgen-receptor negative cell lines PC-3 and PC-3M-Pro4. Moreover, we found that GSK-3 $\beta$ inhibition mainly acts on cancer stem/progenitor-like cells which were shown to be largely androgen-independent $[9,32]$. It appears, therefore, that the drastic anti-tumor effects of GSK- $3 \beta$ inhibition cannot be solely explained by modulation of the androgen-receptor axis.

GSK-3 $\beta$ is typically known for its role in the Wnt signaling pathway, in which it phosphorylates $\beta$-catenin in the absence of Wnt signaling. As expected, inhibition of GSK-3 $\beta$ resulted in increased Wnt signaling in the tested prostate cancer cell lines. To date, the exact role of Wnt signaling in prostate cancer progression has remained controversial. The observations that various Wnt antagonists like members of the Dickkopf (Dkk) family are highly expressed in osteotropic prostate cancer cells [33], upregulated in prostate cancer patients [34] and that stable expression of Dkk-1 stimulates prostate cancer growth [35] all suggest that decreased Wnt signaling may also be beneficial for metastatic outgrowth.

Our data indicate that increased Wnt signaling is not mechanistically involved in the observed anti-tumor effects mediated by pharmacologic GSK-3 $\beta$ inhibition. Blocking Wnt signaling by downstream inhibition of the $\beta$-catenin/TCF interaction after GSK-3 $\beta$ inhibition does not restore the stem/progenitor-like subpopulation and their clonogenic and migratory potential. Hence, it appears that GSK-3 $\beta$ activity is involved in prostate cancer stemness and migration via a Wnt-independent mechanism. However, other studies have shown that 
Wnt signaling is involved in prostate cancer growth as was shown by increased sphere formation upon exogenous addition of Wnt3a [36] and anti-tumor effects upon Wnt inhibition [37-39] (reviewed in [40]). Also, (embryonic or hematopoietic) stem cells appear to be largely dependent on Wnt signaling [41, 42], pointing out a positive correlation of Wnt signaling and stemness. It seems, therefore, that the observed anti-tumor effects of GSK-3 $\beta$ attenuation overrule the previously described pro-tumor effects of Wnt hyperactivation. Strikingly, in mixed-lineage leukemia, activation of Wnt signaling was sufficient to (partially) revert anti-tumor effects of GSK$3 \beta$ inhibition, and combined blockage of GSK-3 $\beta$ and $\beta$-catenin was required to achieve tumor regression [43].

Next, we hypothesized that the effect of GSK-3 $\beta$ inhibition may be mediated via its effect on cytoskeletal rearrangements, in particular the actin cytoskeleton. The regulation of the actin cytoskeleton [23] and focal adhesions [44] were previously linked with GSK-3 $\beta$ activity. In non-transformed cells, i.e. hematopoietic stem and progenitor cells, GSK-3 $\beta$ can influence F-actin polymerization through Rac, Arf6 and Rho activation which results in lamellipodia formation and this is an essential process in cellular migration. Here, inhibition of GSK $-3 \beta$ resulted in reduced motility through interference with actin polymerization [45]. In our studies, we observed a strong reduction of F-actin polymerization upon GSK$3 \beta$ inhibition, which appears to be the predominant mechanism involved in the suppression of cellular migration in vitro and tumorigenicity and metastasis in vivo. Furthermore, we found that GSK-3 $\beta$ inhibition led to a reduction of integrin $\alpha v, \alpha-2$ and $\alpha 6$ expression, possibly mediated via the association of these integrins with F-actin $[24,25]$. As integrin signaling was previously shown to be involved in cancer stem/progenitor cell maintenance $[21,46,47]$ and bone metastasis [22, 48-50], we strongly believe that the disturbance of F-actin via GSK-3 $\beta$ inhibition, thereby leading to reduced integrin-mediated adhesion and signaling, is responsible for the decrease in prostate cancer stemness and bone metastasis.

Taken together, our mechanistic observations highlight the importance of GSK-3 $\beta$ activity in the maintenance of prostate cancer stem/progenitor-like cells and prostate cancer progression in vivo. Current findings with pharmacologic GSK-3 $\beta$ inhibitors may, thus, facilitate the development of novel therapy for incurable, advanced prostate cancer.

\section{METHODS}

\section{Cell lines and culture conditions}

The human prostate cancer cell lines PC-3 and PC3M-Pro4 were cultured in Dulbecco's modified Eagle's medium (DMEM, GibcoBRL) containing 4.5g glucose/L supplemented with 10\% FCII (ThermoScientific), $100 \mathrm{u} /$ $\mathrm{mL}$ penicillin and $50 \mu \mathrm{g} / \mathrm{mL}$ streptomycin (Gibco). For the luciferase expressing PC-3M-Pro4luc2 cells, the previous medium was supplemented with $800 \mu \mathrm{g} / \mathrm{mL}$ G-418 (Neomycin, Invitrogen). C4-2B4 cells were cultured in DMEM (Sigma) supplemented with F-12K nutrient mixture Kaighn's modification (Life Technologies), 10\% FCS, $100 \mathrm{u} / \mathrm{mL}$ penicillin and $50 \mu \mathrm{g} / \mathrm{mL}$ streptomycin, insulin-transferin-selenium (Gibco), biotin, adenine and T3. DU-145 cells were cultured in DMEM supplemented with $10 \%$ FCS, $100 \mathrm{u} / \mathrm{mL}$ penicillin and $50 \mu \mathrm{g} / \mathrm{mL}$ streptomycin. All cell lines were grown in a humidified incubator at $37^{\circ} \mathrm{C}$ and $5 \% \mathrm{CO} 2$.

\section{Transient transfection and luciferase reporter assay}

PC-3 or PC-3M-Pro4 cells were seeded 10000 cells in $500 \mu \mathrm{L}$ medium in a 24-wells plate. Fugene HD transfection reagent (Promega) was used according manufacturer's protocol. For each well, $500 \mathrm{ng}$ of BATluciferase and $25 \mathrm{ng}$ CAGGS-renilla were transfected. After 24 hours, medium was replaced and cells were pretreated with 30-100 $\mu \mathrm{M}$ PNU-74654 (Sigma-Aldrich) for 1 hour before stimulation with 50-100 nM GIN for 24 hours. The luciferase and renilla levels in the lysates were measured using Dual Luciferase Assay (Promega).

\section{Flow cytometry}

PC-3, PC-3M-Pro4luc2, C4-2B4 and DU-145 cells were seeded 500000 cells in $5 \mathrm{~mL}$ medium in a T25. After 16 hours, cells were incubated with 30-100 $\mu \mathrm{M}$ PNU$74654 \mathrm{and} /$ or $100 \mathrm{nM}$ GIN. After 48 hours of treatment, cells were washed and harvested and ALDH activity was determined using the ALDEFLUOR assay kit (StemCell Technologies, Durham, USA). Expression of integrins was measured using the following antibodies: $\alpha 6-\mathrm{APC}, \alpha \mathrm{v}-\mathrm{PE}$ and $\alpha 2$-FITC (Miltenyi). BD FACS caliburTM [10] was used for analysis.

\section{Clonogenic assay}

PC-3, PC-3M-Pro4luc2, C4-2B4 or DU-145 cells were seeded 1 cell per well in a 96-well plate. After 16 hours, cells were pretreated with 30-100 $\mu \mathrm{M}$ PNU-74654 for 1 hour and then treated with $100 \mathrm{nM}$ GIN. After 6-8 days, colonies were counted using light microscopy (Zeiss Axiovert 200M; [15]). 


\section{Migration assay}

Cells were starved with $0.3 \%$ serum overnight and seeded 60000 cells (PC-3, PC-3M-Pro4luc2 and C4-2B4) or 20000 cells (DU-145) per Boyden Chamber (poresize $8.0 \mu \mathrm{m}$, Costar). Cells were allowed to migrate for 16 hours under the presence of 30-100 $\mu \mathrm{M}$ PNU-74654 and/ or $100 \mathrm{nM} \mathrm{GIN}$ and were fixated using $\mathrm{MeOH}$ and stained with crystal violet (Merck; [10]).

\section{Real-time qPCR analysis}

RNA was extracted using Trizol (Invitrogen) and cDNA was synthesized by reverse transcription (Promega, Madison, USA) according to manufacturer's instructions. For real-time qPCR, Biorad IQ5 cycler was used. Gene expression was measured relative to GAPDH expression [16].

\section{Animal studies}

Male Balb-c nu/nu mice were housed in ventilated cages under sterile conditions according to the local guidelines for laboratory animals (DEC12181). PC-3MPro4luc2 cells were seeded 400000 cells $/ 8 \mathrm{~mL}$ medium in T75s and pretreated with $100 \mathrm{nM}$ GIN for $48 \mathrm{~h}$. Cells were harvested and the amount of viable cells was determined using trypan blue exclusion. Two vehicle or GIN-pretreated single cell suspensions were inoculated subcutaneously (100 000 cells in $50 \mu 1 \mathrm{PBS}$ ) into 8-weekold Balb-c nu/nu mice. Similarly, single cell suspensions of vehicle or GIN-pretreated cells were inoculated in the left cardiac ventricle (100 000 cells in $100 \mu \mathrm{l}$ PBS) of 5 -week-old male Balb-c nu/nu mice. Tumor growth was monitored twice weekly by bioluminescent imaging (IVIS Illumina; [10]).

\section{Confocal microscopy}

PC-3 or PC-3M-Pro4luc2 cells were seeded at a density of 5000 cells per $200 \mu \mathrm{L}$ medium onto glass slides and treated with $100 \mu \mathrm{M}$ PNU-74654 and/or $100 \mathrm{nM}$ GIN. After 48h, cells were fixed with acetone, stained with $0.25 \mu \mathrm{M}$ Phalloidin (Life technologies) and sealed with vectashield/DAPI (Vector Laboratories). Confocal microscopy (Leica SP5) was used for analysis of Phalloidin and DAPI.

\section{Statistical analysis}

Statistical analysis was performed using GraphPad Prims 5.0 sofware (San Diego, CA) using either t-test (for comparison between two groups) or ANOVA (for comparison between more than two groups). Data is presented as mean \pm SEM. Significant differences are indicated with asterisks $(* \mathrm{P}<0.05$, ** $\mathrm{P}<0.01$, *** $\mathrm{P}<0.001)$ or dollar signs $(\$ \mathrm{P}<0.05, \$ \$<0.01, \$ \$ \$<0.001)$.

\section{Conflict of interest}

The authors declare no conflict of interest.

\section{ACKNOWLEDGEMENTS}

This study was supported by a grant from the NanoNextNL Drug Delivery Programme (3-D), project number 03D.01. HC, JB and GvdH are funded by Agentschap.nl; PRONET (International Innovation grant), Netherlands Organization for Scientific Research (NWO, VENI-Grant, 916.131.10) and the Dutch Cancer Society (UL-2011-4930), respectively.

\section{REFERENCES}

1. Jemal A, Center MM, DeSantis C and Ward EM. Global patterns of cancer incidence and mortality rates and trends. Cancer Epidemiol Biomarkers Prev. 2010; 19(8):18931907.

2. Wirth MP, See WA, McLeod DG, Iversen P, Morris T, Carroll $\mathrm{K}$ and Casodex Early Prostate Cancer Trialists G. Bicalutamide $150 \mathrm{mg}$ in addition to standard care in patients with localized or locally advanced prostate cancer: results from the second analysis of the early prostate cancer program at median followup of 5.4 years. J Urol. 2004; 172(5 Pt 1):1865-1870.

3. Petrylak DP, Tangen CM, Hussain MH, Lara PN, Jr., Jones JA, Taplin ME, Burch PA, Berry D, Moinpour C, Kohli M, Benson MC, Small EJ, Raghavan D and Crawford ED. Docetaxel and estramustine compared with mitoxantrone and prednisone for advanced refractory prostate cancer. $\mathrm{N}$ Engl J Med. 2004; 351(15):1513-1520.

4. Tannock IF, de Wit R, Berry WR, Horti J, Pluzanska A, Chi KN, Oudard S, Theodore C, James ND, Turesson I, Rosenthal MA, Eisenberger MA and Investigators TAX. Docetaxel plus prednisone or mitoxantrone plus prednisone for advanced prostate cancer. N Engl J Med. 2004; 351(15):1502-1512.

5. Attard G, Reid AH, Yap TA, Raynaud F, Dowsett M, Settatree S, Barrett M, Parker C, Martins V, Folkerd E, Clark J, Cooper CS, Kaye SB, Dearnaley D, Lee G and de Bono JS. Phase I clinical trial of a selective inhibitor of CYP17, abiraterone acetate, confirms that castrationresistant prostate cancer commonly remains hormone driven. J Clin Oncol. 2008; 26(28):4563-4571.

6. Dean M, Fojo T and Bates S. Tumour stem cells and drug resistance. Nat Rev Cancer. 2005; 5(4):275-284.

7. Wang X, Kruithof-de Julio M, Economides KD, Walker D, 
Yu H, Halili MV, Hu YP, Price SM, Abate-Shen C and Shen MM. A luminal epithelial stem cell that is a cell of origin for prostate cancer. Nature. 2009; 461(7263):495500.

8. Germann M, Wetterwald A, Guzman-Ramirez N, van der Pluijm G, Culig Z, Cecchini MG, Williams ED and Thalmann GN. Stem-like cells with luminal progenitor phenotype survive castration in human prostate cancer. Stem Cells. 2012; 30(6):1076-1086.

9. Collins AT, Berry PA, Hyde C, Stower MJ and Maitland NJ. Prospective identification of tumorigenic prostate cancer stem cells. Cancer research. 2005; 65(23):1094610951.

10. van den Hoogen C, van der Horst G, Cheung H, Buijs JT, Lippitt JM, Guzman-Ramirez N, Hamdy FC, Eaton CL, Thalmann GN, Cecchini MG, Pelger RC and van der Pluijm G. High aldehyde dehydrogenase activity identifies tumorinitiating and metastasis-initiating cells in human prostate cancer. Cancer research. 2010; 70(12):5163-5173.

11. Rayasam GV, Tulasi VK, Sodhi R, Davis JA and Ray A. Glycogen synthase kinase 3: more than a namesake. Br J Pharmacol. 2009; 156(6):885-898.

12. Jope RS and Johnson GV. The glamour and gloom of glycogen synthase kinase-3. Trends Biochem Sci. 2004; 29(2):95-102.

13. Reya $\mathrm{T}$ and Clevers $\mathrm{H}$. Wnt signalling in stem cells and cancer. Nature. 2005; 434(7035):843-850.

14. Clevers H. Wnt/beta-catenin signaling in development and disease. Cell. 2006; 127(3):469-480.

15. Li H, Chen X, Calhoun-Davis T, Claypool $\mathrm{K}$ and Tang DG. PC3 human prostate carcinoma cell holoclones contain self-renewing tumor-initiating cells. Cancer research. 2008; 68(6):1820-1825.

16. van den Hoogen $C$, van der Horst $G$, Cheung H, Buijs JT, Pelger RC and van der Pluijm G. The aldehyde dehydrogenase enzyme 7A1 is functionally involved in prostate cancer bone metastasis. Clin Exp Metastasis. 2011; 28(7):615-625

17. Engler TA, Henry JR, Malhotra S, Cunningham B, Furness K, Brozinick J, Burkholder TP, Clay MP, Clayton J, Diefenbacher C, Hawkins E, Iversen PW, Li Y, Lindstrom TD, Marquart AL, McLean J, et al. Substituted 3-imidazo[1,2-a]pyridin-3-yl- 4-(1,2,3,4-tetrahydro-[1,4] diazepino-[6,7,1-hi]indol-7-yl)pyrrole-2,5-diones as highly selective and potent inhibitors of glycogen synthase kinase-3. J Med Chem. 2004; 47(16):3934-3937.

18. Miclea RL, Siebelt M, Finos L, Goeman JJ, Lowik CW, Oostdijk W, Weinans H, Wit JM, Robanus-Maandag EC and Karperien M. Inhibition of Gsk3beta in cartilage induces osteoarthritic features through activation of the canonical Wnt signaling pathway. Osteoarthritis Cartilage. 2011; 19(11):1363-1372.

19. van Bezooijen RL, Svensson JP, Eefting D, Visser A, van der Horst G, Karperien M, Quax PH, Vrieling H,
Papapoulos SE, ten Dijke P and Lowik CW. Wnt but not BMP signaling is involved in the inhibitory action of sclerostin on BMP-stimulated bone formation. J Bone Miner Res. 2007; 22(1):19-28.

20. Maretto S, Cordenonsi M, Dupont S, Braghetta P, Broccoli V, Hassan AB, Volpin D, Bressan GM and Piccolo S. Mapping Wnt/beta-catenin signaling during mouse development and in colorectal tumors. Proc Natl Acad Sci U S A. 2003; 100(6):3299-3304.

21. van den Hoogen C, van der Horst G, Cheung H, Buijs JT, Pelger RC and van der Pluijm G. Integrin alphav expression is required for the acquisition of a metastatic stem/progenitor cell phenotype in human prostate cancer. Am J Pathol. 2011; 179(5):2559-2568.

22. Sottnik JL, Daignault-Newton S, Zhang X, Morrissey C, Hussain MH, Keller ET and Hall CL. Integrin alpha2beta 1 (alpha 2 beta 1) promotes prostate cancer skeletal metastasis. Clin Exp Metastasis. 2013; 30(5):569-578.

23. Sun A, Shanmugam I, Song J, Terranova PF, Thrasher $\mathrm{JB}$ and $\mathrm{Li}$ B. Lithium suppresses cell proliferation by interrupting E2F-DNA interaction and subsequently reducing S-phase gene expression in prostate cancer. Prostate. 2007; 67(9):976-988.

24. Case LB and Waterman CM. Adhesive F-actin waves: a novel integrin-mediated adhesion complex coupled to ventral actin polymerization. PLoS One. 2011; 6(11):e26631.

25. Yu CH, Law JB, Suryana M, Low HY and Sheetz MP. Early integrin binding to Arg-Gly-Asp peptide activates actin polymerization and contractile movement that stimulates outward translocation. Proc Natl Acad Sci U S A. 2011; 108(51):20585-20590.

26. Korur S, Huber RM, Sivasankaran B, Petrich M, Morin P, Jr., Hemmings BA, Merlo A and Lino MM. GSK3beta regulates differentiation and growth arrest in glioblastoma. PLoS One. 2009; 4(10):e7443.

27. Fotovati A, Abu-Ali S, Wang PS, Deleyrolle LP, Lee C, Triscott J, Chen JY, Franciosi S, Nakamura Y, Sugita Y, Uchiumi T, Kuwano M, Leavitt BR, Singh SK, Jury A, Jones $\mathrm{C}$, et al. YB-1 bridges neural stem cells and brain tumor-initiating cells via its roles in differentiation and cell growth. Cancer research. 2011; 71(16):5569-5578.

28. Zhu Q, Yang J, Han S, Liu J, Holzbeierlein J, Thrasher JB and Li B. Suppression of glycogen synthase kinase 3 activity reduces tumor growth of prostate cancer in vivo. Prostate. 2011; 71(8):835-845.

29. Mai W, Kawakami K, Shakoori A, Kyo S, Miyashita K, Yokoi K, Jin M, Shimasaki T, Motoo Y and Minamoto T. Deregulated GSK3 \{beta\} sustains gastrointestinal cancer cells survival by modulating human telomerase reverse transcriptase and telomerase. Clinical cancer research : an official journal of the American Association for Cancer Research. 2009; 15(22):6810-6819.

30. Mazor M, Kawano Y, Zhu H, Waxman J and Kypta RM. 
Inhibition of glycogen synthase kinase-3 represses androgen receptor activity and prostate cancer cell growth. Oncogene. 2004; 23(47):7882-7892.

31. Schutz SV, Schrader AJ, Zengerling F, Genze F, Cronauer MV and Schrader M. Inhibition of glycogen synthase kinase-3beta counteracts ligand-independent activity of the androgen receptor in castration resistant prostate cancer. PLoS One. 2011; 6(9):e25341.

32. Maitland NJ, Frame FM, Polson ES, Lewis JL and Collins AT. Prostate cancer stem cells: do they have a basal or luminal phenotype? Horm Cancer. 2011; 2(1):47-61.

33. Schwaninger R, Rentsch CA, Wetterwald A, van der Horst G, van Bezooijen RL, van der Pluijm G, Lowik CW, Ackermann K, Pyerin W, Hamdy FC, Thalmann GN and Cecchini MG. Lack of noggin expression by cancer cells is a determinant of the osteoblast response in bone metastases. Am J Pathol. 2007; 170(1):160-175.

34. Zenzmaier C, Heitz M, Klocker H, Buck M, Gardiner RA and Berger P. Elevated levels of Dickkopf-related protein 3 in seminal plasma of prostate cancer patients. J Transl Med. 2011; 9:193.

35. Thudi NK, Martin CK, Murahari S, Shu ST, Lanigan LG, Werbeck JL, Keller ET, McCauley LK, Pinzone JJ and Rosol TJ. Dickkopf-1 (DKK-1) stimulated prostate cancer growth and metastasis and inhibited bone formation in osteoblastic bone metastases. Prostate. 2011; 71(6):615625.

36. Bisson I and Prowse DM. WNT signaling regulates selfrenewal and differentiation of prostate cancer cells with stem cell characteristics. Cell Res. 2009; 19(6):683-697.

37. Yee DS, Tang Y, Li X, Liu Z, Guo Y, Ghaffar S, McQueen P, Atreya D, Xie J, Simoneau AR, Hoang BH and Zi X. The Wnt inhibitory factor 1 restoration in prostate cancer cells was associated with reduced tumor growth, decreased capacity of cell migration and invasion and a reversal of epithelial to mesenchymal transition. Mol Cancer. 2010; 9:162.

38. Lin C, Lu W, Zhai L, Bethea T, Berry K, Qu Z, Waud WR and $\mathrm{Li} \mathrm{Y}$. Mesd is a general inhibitor of different Wnt ligands in Wnt/LRP signaling and inhibits PC-3 tumor growth in vivo. FEBS Lett. 2011; 585(19):3120-3125.

39. Thamilselvan V, Menon M and Thamilselvan S. Anticancer efficacy of deguelin in human prostate cancer cells targeting glycogen synthase kinase-3 beta/beta-catenin pathway. Int J Cancer. 2011; 129(12):2916-2927.

40. Majid S, Saini S and Dahiya R. Wnt signaling pathways in urological cancers: past decades and still growing. Mol Cancer. 2012; 11:7.

41. Trowbridge JJ, Xenocostas A, Moon RT and Bhatia M. Glycogen synthase kinase-3 is an in vivo regulator of hematopoietic stem cell repopulation. Nat Med. 2006; 12(1):89-98.

42. Sato N, Meijer L, Skaltsounis L, Greengard P and Brivanlou $\mathrm{AH}$. Maintenance of pluripotency in human and mouse embryonic stem cells through activation of Wnt signaling by a pharmacological GSK-3-specific inhibitor. Nat Med. 2004; 10(1):55-63.

43. Fung TK, Gandillet A and So CW. Selective treatment of mixed-lineage leukemia leukemic stem cells through targeting glycogen synthase kinase 3 and the canonical Wnt/beta-catenin pathway. Curr Opin Hematol. 2012; 19(4):280-286.

44. Kobayashi T, Hino S, Oue N, Asahara T, Zollo M, Yasui $\mathrm{W}$ and Kikuchi A. Glycogen synthase kinase 3 and h-prune regulate cell migration by modulating focal adhesions. Mol Cell Biol. 2006; 26(3):898-911.

45. Lapid K, Itkin T, D’Uva G, Ovadya Y, Ludin A, Caglio G, Kalinkovich A, Golan K, Porat Z, Zollo M and Lapidot T. GSK3beta regulates physiological migration of stem/ progenitor cells via cytoskeletal rearrangement. J Clin Invest. 2013; 123(4):1705-1717.

46. Marthick JR and Dickinson JL. Emerging putative biomarkers: the role of alpha 2 and 6 integrins in susceptibility, treatment, and prognosis. Prostate Cancer. 2012; 2012:298732.

47. Lipscomb EA and Mercurio AM. Mobilization and activation of a signaling competent alpha6beta4integrin underlies its contribution to carcinoma progression. Cancer Metastasis Rev. 2005; 24(3):413-423.

48. Colombel M, Eaton CL, Hamdy F, Ricci E, van der Pluijm G, Cecchini M, Mege-Lechevallier F, Clezardin P and Thalmann G. Increased expression of putative cancer stem cell markers in primary prostate cancer is associated with progression of bone metastases. Prostate. 2012; 72(7):713720 .

49. van der Horst G, van den Hoogen C, Buijs JT, Cheung H, Bloys H, Pelger RC, Lorenzon G, Heckmann B, Feyen J, Pujuguet P, Blanque R, Clement-Lacroix $\mathrm{P}$ and van der Pluijm G. Targeting of alpha(v)-integrins in stem/ progenitor cells and supportive microenvironment impairs bone metastasis in human prostate cancer. Neoplasia. 2011; 13(6):516-525.

50. Eaton CL, Colombel M, van der Pluijm G, Cecchini M, Wetterwald A, Lippitt J, Rehman I, Hamdy F and Thalman G. Evaluation of the frequency of putative prostate cancer stem cells in primary and metastatic prostate cancer. Prostate. 2010; 70(8):875-882. 